\title{
Sosyal Medyada Çocuk Hakları İhlali ve Çocuk İstismarı: Instagram Anneleri*
}

\author{
Children's Rights Violation And Child Abuse In Social Media: Instamoms
}

\author{
Ayten Güngör, Öğr. Gör., Muğla Sitkı Koçman Üniversitesi Basın Halkla İlişkiler ve Protokol Müdürlüğü, \\ E-posta: aytengungor@mu.edu.tr
}

https://doi.org/10.47998/ikad.836192

\author{
Anahtar Kelimeler: \\ Sosyal Medya, \\ Çocuk Hakları, \\ Çocuk İstismarı, \\ Instagram Anneleri.
}

\section{$\ddot{O} z$}

Dijital devrim, toplumsal yaşamda önemli değişimler yaratarak insanoğlunun iletişim kurma yöntemlerine bir yenisini eklemiştir. Dünyayı değiştiren ve değişen dünyaya hızla ayak uyduran bu yeni iletişim platformunun adı sosyal medyadır. Sanallığın gerçekliğe hükmettiği bu platform politikadan, ekonomiye, ticaretten, eğitime tüm sistemleri kendi ortamına taşıyarak onları değişime zorlamıştır. Bu noktada dijitalleşen iletişim ağlarına dâhil olmak isteyen yeni nesil anneler, anneliği sayısal dünyanın dokusuna dönüştürerek kendilerine yeni bir var olma alanı yaratmıştır. Sosyal medya ortamlarında gerçekleşen çocuk istismarı ve hak ihlalleri üzerinde durulan bu çalışma ile annelerin çocuk hakları ihlallerine ve çocuk istismarına neden olacak paylaşımlarının analizi yapılarak konuyla ilgili farkındalık yaratılması ve yasa koyucular, ilgili kurumlar ve ebeveynler için bilimsel bir rehber oluşturulması amaçlanmıştır. Bu çerçevede çocuk istismarı ve hak ihlallerinin sosyal medya üzerinden ne şekilde gerçekleştiği, pedofili ve sosyal medya paylaşımları arasındaki ilişki netnografik araştırma yöntemi ile incelenmiştir. Çalışma sonucu, örneklem olarak belirlenen 5 annenin hesabında çeşitli biçimlerde çocuk haklarının ihlal edildiği ve çocuğun istismar edildiği tespit edilmiştir.

\section{Keywords:}

Social Media, Child Rights, Child Abuse, Instamom.

\section{Abstract}

The digital revolution has added a new way of humankind's communication methods by creating significant changes in social life. This new communication platform that changes the world and also rapidly keeps up with the changing world is called as "Social Media". This platform, where virtuality dominates reality, has forced all systems, from politics to economy, commerce to education, to change by moving them to its own environment. At this point, new generation mothers who want to be included in digitalized communication networks have created a new existence for themselves by transforming motherhood into the fabric of digital world. With this reserch, which focuses on child abuse and violation of children's rights in social media environments, it is aimed to raise awareness on the issue by analyzing mothers' posts that will cause child rights violations and child abuse, and to create a scientific guide for legislators, relevant institutions and parents. How child abuse and violations of rights occur on social media, the relationship between pedophilia and social media posts was analyzed by netnographic research method. As a result of the study, it was determined that the child rights were violated and the child was abused in various ways in the account of 5 mothers' determined as a sample.

*Bu çalışma, Marmara Üniversitesi Sosyal Bilimler Enstitüsü Gazetecilik Ana Bilim Dalı'nda tamamlanmış olan “Sosyal Medyada Çocuk Hakları İhlali ve İstismarı: Instagram Anneleri” başlıklı yüksek lisans tezinden üretilmiştir.

$\begin{array}{ll}\text { Araştırmacı Orcid ID } & : 0000-0003-2177-901 X \\ \text { Geliş Tarihi } & : 05.12 .2020 \\ \text { Kabul Tarihi } & : 18.05 .2021\end{array}$




\section{Giriş}

Varlığını kabul ettirmek, insanoğlunun en büyük zaafıdır. Bu zaafın tatmini, ancak duygu ve düşüncelerin aktarımı ile gerçekleşebilir. Yüzyılımız ise duygu ve düşüncelerin paylaşılması için neredeyse sınırsız bir alan sunmaktadır. İnsanoğlunun milyarlarca yıldır süren varlığını kabul ettirme mücadelesi, yine kendi aklı ve zekâsıyla var ettiği yeni bir alanda, sonsuzluğun sınırına dayanmıştır. Artık var olmak ve sesini duyurabilmek hiç olmadığı kadar kolay ve zamansızdır. Tek bir fikir, bir düşünce, bir fotoğraf, bir an bir "tık" sesi zamanda; herhangi bir anda ya da mekânda bir araya gelemeyecek insanlara dahi ulaşabilmektedir. Bu yeni iletişim kurma biçimi zamanı ve mekânı ortan kaldırırken, eylemin "geri dönülemezliğini” de bir sorun olarak karşımıza çıkarmaktadır. Artık iletinin içeriği, her zamankinden daha önemlidir. Çünkü bu iletiler kişinin handiyse "kimliğini" yaratmakta ve yaratılan bu kimlik sanal düzlemde sonsuza dek kayıt altında kalmaktadır.

Tam da bu noktada dijitalleşen iletişim ağlarına dâhil olmak isteyen yeni nesil anneler, anneliği sayısal dünyanın dokusuna dönüştürerek kendilerine yeni bir var olma alanı yaratmıştır. Toplumdan topluma, kuşaktan kuşağa değişen çocuk yetiştirme ritüelleri, sosyal ağlarla birlikte görünürlük kazanmıştır. Sosyal ağlar içerisinde Instagram ise görselliği ön plana çıkaran yapısı sayesinde yeni nesil annelerin "Instamom" kavramını var ettiği bir alan haline gelmiştir. Anne-babaların çocuklarının her anını sosyal ağlar üzerinden paylaşması, onları teşhir etmesi ve bu paylaşımlardan ticari kazanç sağlaması sosyal medya ile birlikte hayatımıza giren bir davranış biçimidir. Henüz karar verebilme yetisine sahip olmayan çocukların, mahrem görüntülerinin milyonlarca kişiye sunulması, çocuğun yetişkinlikte yaşayacağ 1 psikolojik yıkımlar ile birlikte mahremiyet bilinci kazanamamasına da neden olmaktadır. Aynı zamanda herkese açık yapılan paylaşımlar, çocukların güvenliğini tehlikeye düşürmekte ve pedofili hastalarına kurbanlarını bulmaları yönünde yardımcı olmaktadır. Yapılan birçok araştırmada da görüldüğü üzere, pedofili sitelerinde yer alan paylaşımların yaklaşık yarısının sosyal medya hesaplarından kopyalandığı bilinmektedir. Bu durumun çocuklar üzerinde yaratacağı yıkımlar ise belki de önümüzdeki yılların en büyük hukuki problemi olacaktır.

\section{Dünyada ve Türkiye'de Çocuk Hakları}

Çocuğun korunması, onun "bir insan" olarak sevgi ve şefkate layık olması yanında, toplumun bir parçası olması fikrine dayanır (İnan, 1968: 9). Çocuğun korunması, içinde yer aldığ1 ilk toplumsal kurum olan aileden başlar. Aile, çocuğun ruhsal, bedensel, fiziksel yönden korunması ve gelişimi için ilk ve en önemli kurumdur. Çocuğun sağlıklı bir ortamda yetişmesi ailenin vicdani ve ahlaki sorumluluğu olmasının yanında ayrıca yasalarla da hukuk çerçevesi içerisinde düzenlenmiştir. Birleşmiş Milletler (BM) Çocuk Hakları Sözleşmesi'nin 18. maddesi bu durumu "Çocuğun yetiştirilmesi ve geliştirilmesi sorumluluğu ilk önce ana babaya ya da durum gerektiriyorsa yasal vasilere düşer. $\mathrm{Bu}$ kişiler her şeyden önce çocuğun yüksek yararını göz önünde tutarak hareket ederler" ifadeleriyle açıklar. Ancak çocuğun her türlü kötülükten korunması görevi öncelikli olarak aileye verilmiş olsa da bu noktada devlet sadece aileyi denetlemekle yükümlü değil aynı zamanda çocuğun "yükssek yararını" göz önüne alarak, onun sosyal ve psikolojik gelişimini güvence altına almakla da yükümlüdür (Akyüz, 2011: 18). 
BM Çocuk Hakları Sözleşmesi, çocuk hakları ile ilgili en geniş kapsamlı sözleşmedir. BM Çocuk Hakları Sözleşmesi'ne göre 18 yaşına kadar her insan çocuk sayılır ve sosyal yardım kuruluşları, mahkemeler, idari makamlar ve hukuki düzenlemeler gibi çocukları ilgilendiren tüm faaliyetlerde çocuğun yüksek yararı göz önüne alınır. Çocuğun temel yaşama hakkı sözleşmeye taraf devletlerin kabul ettiği temel haktır. Taraf devletler, çocuğun korunması ile ilgili gerekli tüm tedbirleri almakla birlikte, çocuğun güvenliği ve bakımından sorumlu her türlü kurum ve kişileri denetlemekle ve onlara sorumluluklarını yerine getirebilmeleri için her türlü imkânı sağlamakla mükelleftir.

Birleşmiş Milletler Çocuklara Yardım Fonu (UNICEF) dünyada çocuk hakları ve refahı ile ilgili çalışmalar yapan en büyük kurumdur. Bu çalışmalar kapsamında çocukların refahını artırmak, eğitime erişimlerini kolaylaştırmak, becerilerini pratiğe aktarmalarını sağlamak ve sağlıklı yaşam ortamları yaratmak için dünyanın birçok ülkesinde çeşitli kurumlarla ortak iş birlikleri gerçekleştirmektedir. UNICEF, özellikle gelişmemiş ülkelerde bulunan çocukların refahını arttırmak için yoğun çaba sarf etse de, toplam 190 ülkede varlık gösterir (UNICEF Ne Yapar?, 2018).

Türkiye İstatistik Kurumunun (TÜİK) 2020 verilerine göre Türkiye'de toplam nüfusun yüzde 22,8'i yani 19 milyon 064 bin 074'ü çocuklardan oluşmaktadır. Çocuk nüfusunun toplam nüfusa oranının yıllar içinde düşeceği öngörülse de bu veriler Avrupa'nın üstündedir. Bu noktada çocuklarla ilgili izlenecek politikalar daha da önem kazanmaktadır. Türkiye, çocuk hakları ile ilgili yasal çerçevesini 14 Eylül 1990 tarihinde imzaladığı Çocuk Haklarına Dair Sözleşme ile belirlemiştir. Bununla birlikte evrensel insan hakları yasalarına paralel olarak birçok yasada çocuk haklarına ilişkin özel düzenlemelere rastlamak mümkündür. Örneğin Türk Medeni Kanunu'nun 346., 347. ve 348. maddeleri çocuğun yüksek yararının gözetilmesi ile ilgili alınan kararları içermektedir. Bu kanun maddesi, çocuğun bakımından birinci derece sorumlu anne-babanın, çocuğu herhangi bir olumsuz durumda koruyamayacağı anlaşıldığında, gerekli önlemlerin alınması ve çocuğun güvenliğinin sağlanması ile ilgilidir.

15 Temmuz 2005 tarihinde Resmi Gazete'de yayımlanarak yürürlüğe giren 5395 sayılı Çocuk Koruma Kanunu ise giriş kısmında belirtildiği üzere korunma ihtiyacı olan veya suça sürüklenen çocukların korunmasına, haklarının ve esenliklerinin güvence altına alınmasına ilişkin usul ve esasları kapsamaktadır. Çocuk Koruma Kanunu, çocuğun taraf olduğu davalarda davanın soruşturma aşamasından cezanın infazı aşamasına kadar izlenecek yolları, çocuğa özel mahkemelerin kuruluş, yetki ve görevlerini, çocuğun korunmasını sağlamaya yönelik danışmanlık, eğitim, bakım, sağlık ve barınma konularında alınacak tedbirleri, Cumhuriyet Başsavcılıklarında oluşturulacak çocuk bürolarının görev ve yetkileri, çocuk ve aile sorunları ile çocuk hukuku ve çocuk suçluluğunun önlenmesi alanlarında çalışacak sosyal çalışma görevlilerinin görevlerini çocuk lehine düzenlemiş ve çocuğun suçtan arındırılmasını ve korunmasını temel almıştır.

Türk Ceza Kanunu (TCK), çocuklar ile ilgili maddelerin yer aldığı bir diğer yasadır. TCK'nın 6. maddesinin 1. fikrasında 18 yaşını doldurmamış kişi çocuk kabul edilmektedir. Yine aynı kanunda çocuğun ceza sorumluluğunun başladığı yaş sınırı 12 olarak belirlenmiştir. Ülkemizde çocuğun belli hakları üzerinden gerçekleştirilen 
kampanyalar da çocuk haklarının hükümet dışı kaynak ve yöntemlerle yerine getirilmesini sağlamaktadır. Bu tarz sosyal sorumluluk projeleri çocuklara görünür faydalar sağlamakla beraber, çocuk haklarını gündemde tutarak toplumsal duyarlılığı arttırmaktadır.

\section{Özel Hayatın Gizliliği ve Unutulma Hakkı}

İletişim araçlarının toplumlar ve bireyler üzerinde uzun ya da kısa süreli, yapıcı ya da yıkıcı etkileri olduğu bilinmektedir. Bu etkilere maruz kalma, etkinin niteliğine ve etkilenen grubun özelliğine göre değişmektedir. Yeni medya ise medya-izleyici-etki arasındaki ilişkilere "aktif izleyici" kavramıyla dahil olmuştur. Ancak internet ortamında "izleyici" kavramının yerini "kullanıcı" almıştır. Geleneksel medyada çocukların iletişim sürecine dahili sınırlı iken, yeni medyada mesajlar bizzat bireyler tarafindan ve herhangi bir denetime tabi tutulmadan yayılmaktadır. Bir enformasyon kaynağı olarak yeni medya sınırsız bir güce sahiptir. Bu nedenle etkileri konusunda farklı yorumlar vardır. Ancak denetlenmesindeki zorluklar nedeniyle çocuklar için yıkıcı sonuçlara neden olabilmektedir (Timisi, 2011: 143).

Çocuk, sosyal ağlarla birlikte hiç olmadığı kadar medya iletilerinin içerisinde yer almıştır. Ebeveynler kendi medya iletilerine çocuklarla ilgili görselleri ve enformasyonu dahil ederek, onları sosyal medyanın kimi zaman bizzat iletisi kimi zaman da kullanıcisı haline getirmiştir. Çocuğun, gelişim süreçlerine uygun olmayan bir biçimde iletişim sürecine dahil edilmesi beraberinde hak ihlallerini ve istismarı getirmiştir. Sosyal medya ile ilgili özel bir düzenlemenin bulunmaması ise bu ihlallerin ve istismarın anlaşılmasını güçleştirmektedir. Sosyal ağlarda çocuk hakları ihlalleri ya da çocuk istismarı genel olarak, özel hayatın gizliliğinin ihlali ya da unutulma hakkının ihlali ile gerçekleşmektedir.

Özel hayatın gizliliği ile ilgili tartışmaların tam olarak tarihin hangi diliminde başladığı bilinmese de özel yaşamın gizliliği hakkının evrensel düzeyde anlaşılması ve kabul edilmesi 20. yüzyılda yaşanan gelişmeler ile mümkün olmuştur. Özellikle basının gelişmesine denk düşen bu çalışmalar, özel hayatın kapsamını ve özel hayatın gizliliğinin ihlali ile ilgili yaptırımları somut ve evrensel hale getiriştir. Özel yaşam veya mahremiyet genel olarak kişilerin yalnız başına kalabildikleri, istedikleri gibi davranabildikleri, başkalarıyla hangi yer, zaman ve koşullarda ne ölçüde ilişki ve iletişim kuracaklarına bizzat kendilerinin karar verebildikleri bir alan ve bu alan üzerinde sahip olunan hakk1 ifade eder (Yüksel, 2003: 182). BM Genel Kurulunda 1948 y1lında kabul edilen İnsan Hakları Evrensel Bildirgesi'nin 12. maddesi özel yaşamın gizliliğini koruyan en kapsayıcı sözleşme olarak karşımıza çıkmaktadır. Bu bildirgeye göre, "Kimsenin özel yaşamına, ailesine konutuna ya da haberleşmesine keyfi olarak karışılamaz, şeref ve adına saldırılamaz. Herkesin bu gibi karışma ve saldırılara karşı yasa tarafından korunmaya hakkı vardır." Avrupa İnsan Hakları Sözleşmesi'nde de özel yaşamın gizliliği teminat altına alınmıştır. Sözleşmede “Özel ve Aile Hayatına Saygı Hakkı” başlığı altında, herkes özel ve aile hayatına, konutuna ve yazışmasına saygı gösterilmesi hakkına sahiptir denilmektedir.

Avrupa Konseyi Parlamenter Meclisi tarafından kabul edilen Kitlesel İletişim Araçları ve İnsan Hakları Bildirisi'nde mahremiyet hakkı, "Bir kişinin hayatını minimum 
müdahaleyle yaşama hakkı" olarak tanımlanmıştır. Bu hak, aile ve ev yaşamı hakkının, fiziksel ve ruhsal bütünlüğün, şeref ve itibarın korunması, utanç verici durumların yayımlanması ve özel fotoğrafların izinsiz paylaşılması gibi hak ihlallerinden korumayı amaçlamaktadır. Yine Birleşmiş Milletler Genel Kurulu'nda kabul edilerek 23 Mart 1976 tarihinde yürürlüğe giren Kişisel ve Siyasal Haklar Uluslararası Sözleşmesi'nde ise mahremiyet, "Hiç kimsenin özel ve aile yaşamına, konutuna veya haberleşmesine keyfi veya hukuka aykırı olarak müdahale edilemez; onuru veya itibarı hukuka aykırı saldırılara maruz bırakılamaz. Herkes bu tür saldırılara veya müdahalelere karşı hukuk tarafından korunma hakkına sahiptir" ifadeleriyle güvence altına alınmıştır.

Özel hayatın gizliliği ya da mahremiyetin korunması ile ilgili haklar, Türkiye Cumhuriyeti Anayasası'nda da yer almaktadır. Özel Hayatın Gizliliği ve Korunması başlığ 1 altında özel hayatın gizliliği, "Herkes, özel hayatına ve aile hayatına saygı gösterilmesini isteme hakkına sahiptir. Özel hayatın ve aile hayatının gizliliğine dokunulamaz" hükmüyle korunmaktadır. Bununla birlikte yine Anayasa'da Konut Dokunulmazlığ ve Haberleşme Hürriyeti başlıkları altında özel yaşamın dokunulmazlığı koruma altına alınmıştır. Özel hayatın gizliliğinin ihlaline karşı uygulanacak yaptırımlar Türk Ceza Kanunu'nda (TCK) belirlenmiştir. TCK'nın 134. maddesine göre, "Kişilerin özel hayatının gizliliğini ihlal eden kimse, bir yıldan üç yıla kadar hapis cezası ile cezalandırılır. Gizliliğin görüntü veya seslerin kayda alınması suretiyle ihlal edilmesi halinde, verilecek ceza bir kat artırılır."

Teknolojinin ilerlemesi ile kişisel verilerin üçüncü kişilerin eline geçmesi kolaylaşmıştır. Arama motorları ve sosyal medya sayesinde, kişisel bilgiler kamuya açık hale gelmiştir. Bu durumun yarattığı olumsuzları ortadan kaldırma ve daha özgür bir yaşam isteği ile "unutulma hakkı" gündeme gelmiştir. Bu hak genel anlamıyla, "Bireyin dijital ortamda yer alan kişisel verilerinin çeşitli sebeplere bağlı olarak silinmesini ve daha fazla yayılmasının önlenmesini talep etme hakkı" olarak tanımlanabilir (European Commission, 2014). Türkiye'deki kişisel verilerin korunması mevzuatı çocuklara ilişkin özel bir düzenleme içermediğinden, çocukların unutulma hakkına ilişkin düzenlemeler için Avrupa Veri Koruma Tüzüğü’ne başvurulmaktadır (Yavuz, 2020: 37).

Avrupa Komisyonu kişisel verilerin korunması ile ilgili, herkes kendisiyle ilgili kişisel verilerin korunmasını isteme ve kendisiyle ilgili verilere ulaşma ve düzeltilmesini isteme hakkına sahiptir demektedir. Bununla birlikte Anayasa'nın 20. maddesi de, "Herkes, kendisiyle ilgili kişisel verilerin korunmasını isteme hakkına sahiptir. Bu hak; kişinin kendisiyle ilgili kişisel veriler hakkında bilgilendirilme, bu verilere erişme, bunların düzeltilmesini veya silinmesini talep etme ve amaçları doğrultusunda kullanılıp kullanılmadığını öğrenmeyi de kapsar" ifadelerine yer vererek, kişisel verilerin korunması ile ilgili esas ve usulleri belirlemiştir. Yine 2016 yılında kabul edilerek yürürlüğe giren Kişisel Verilerin Korunması Kanunu da "Kişisel verilerin işlenmesinde başta özel hayatın gizliliği olmak üzere kişilerin temel hak ve özgürlüklerini korumak ve kişisel verileri işleyen gerçek ve tüzel kişilerin yükümlülükleri ile uyacakları usul ve esasları düzenleme"yi amaçlamaktadır.

Bireyin kendine ait eylemlerinin ya da herhangi bir enformasyonunun, kendi iradesi dışında kamuya sunulması bu hakkın ihlalinin bir diğer boyutunu oluşturmaktadır. 
$\mathrm{Bu}$ hakkı ihlal eden ve edilen arasında çocuk-ebeveyn ilişkisin olması ise durumu daha kaotik hale getirmektedir. Bireyin özel yaşamının kamuya sunulmasına rıza göstermesi suçu ortadan kaldırır. Ancak duruma çocuk açısından baktığımızda, çocuğun henüz anlamlandıramadığı bir duruma rıza göstermesi, mutlak anlamda rıza gösterdiği anlamına gelemez. "Çocuğun rızası" çocuğun gelişim seyrinde bir kesinliği temsil etmediğinden hukuka da uygun değildir. Çocuğun bakımından ve her türlü hakkını korumaktan sorumlu ebeveynlerin, çocuğunun özel alanını teşhir etmesi çocuğunu istismar etmesi ile eş anlamlıdır. Unutulma hakkı ya da özel hayatın gizliliği kişilik haklarının temelini oluşturur. Bu hakka yapılan her türlü müdahale ise kişilik hakkına yapılan müdahaledir.

\section{Çocuk Hakları İhlali ve İstismar Alanı olarak Sosyal Medya}

Dijitalleşme sosyal hayattan ekonomiye, kültürden eğitime birçok alanı dönüştürmüştür. Çocuklar da dünyaya geldiği andan itibaren dijital ağlarla çevrili bir dünya düzenine dâhil olmuştur. Dijital dünyanın çocukları sınırsız bilgi kanallarına sahipken, sosyalleşmek için de birçok platformu elinde bulundurmaktadır. Prof. Dr. Pier Cesare Rivoltella'nın (2006) kitabının ismi olan “ekran kuşağı” ve Hanna Rosin'in (2013) ifade ettiği "dokunmatik-ekran kuşağı" gelecek nesilleri ifade eden kavramlardır (I. Türkiye Çocuk ve Medya Stratejisi ve Uygulama Planı 2014-2018: 22). Bu yeni dünyanın ekran kuşağı, sosyal medyayı da bir toplumsallaşma aracı olarak kullanmaktadır. Ancak sosyal ağların gerçek yaşama bu denli hızlı ve etkin bir biçimde dâhil olması ve bu ağların bireysel kullanıma yönelik dizayn edilmesi çocuk hakları ihlali ve çocuk istismarı ile ilgili birçok problemi de beraberinde getirmiştir.

Dijital dünya çocuklara hiç tanımadığı insanlarla etkileşim haline geçmesine izin verdiği, gerçek kimliğin manipülasyonuna imkân sağladığı, bunlarla ilintili olarak yalanlarla karşılaşmasına ve cinsel yalanlar ile sözle istismara maruz kalmasına zemin hazırladığı için kısmen zararlıdır (Tüzün, 2002: 48-49). Çocuklar sosyal medya ortamlarında bilgilerini paylaşırken duygusal, fiziksel ve cinsel istismara; aşırı bilgi paylaşımı nedeniyle güvenlik sorunlarına açık hale gelmektedir. Aynı zamanda yapılan paylaşımlara tepki olarak alınan beğeniler ve yeniden paylaşımlar soyut ödüller yerine geçmektedir. Zahmetsizce elde edilen ve ruhu geçici süreliğine de olsa doyurabilen bu ödüller bir kısır döngüyü başlatmaktadır. Ne kadar çok paylaşırsa o kadar ödül alan çocuk; ödül almanın verdiği özgüvenle daha çok paylaşmaktadır. Bu durum alışkanlığ pekiştirerek "bağımlılık sarmalını" beslemektedir (Numedov, 2016: 17). Bununla birlikte çevirim içi kimlik hırsızlığı da sosyal ağlar üzerinden karşılaşılabilecek bir sorundur. Ebeveynler tarafından sosyal ağlara yüklenen videoların ve fotoğrafların, zaman zaman üçüncü kişilerin sosyal medya hesaplarından kendi çocuklarının fotoğrafları ve videolarıymış gibi paylaşıldığı gözlemlenmiştir (Aktaran: Yavuz, 2020: 23). Yine internete yüklenen çocuk fotoğraflarının izinsiz ve hukuka aykırı bir biçimde yüz tanıma sistemlerinin geliştirilmesi amacıyla kullanıldığ 1 da iddia edilmektedir (Yavuz, 2020: 24).

Sosyal ağlar, bilgi paylaşımını ve iletişimi kolaylaştırsa da risklerini de beraberinde getirmiştir. Savunmasız konumda olan çocuklar ise bu riskler ile daha fazla karşı karşıya gelmektedir. Ebeveynler için sosyal ağlar ile ilgili tüm bilgilerin ve tecrübelerin henüz 
yeni olması, buralardan oluşacak risklerin önceden belirlenmesini ve tedbir alınmasını güçleştirmektedir. Zorbalık gibi geleneksel yaşamda da karşılaş1labilen sorunlar, sosyal ağlar üzerinden daha fazla çocuğu ve psikolojik şiddet dozu daha yüksek bir biçimde etkilemektedir. Bununla birlikte sosyal ağların mahremiyeti sınırlayıcı yapısı ve kişisel bilgileri paylaşmaya teşvik edici yönü çocukların güvenliğini tehdit etmektedir. Çocuğun bizzat kendi ya da bir ebeveyni tarafından özel ilgi alanlarının paylaşılması, eğitim gördüğü ya da yaşadığı herhangi bir yerden konum bildirimleri yapılması, çocuğa bakmakla yükümlü olanlar ile ilgili tüm detayların yayınlanması ona ulaşmaya çalışan üçüncü kişiler için fazlasıyla veri sağlamaktadır. Tüm bu masum görünen bilgiler, kötü niyetli kişilerin elinde, eylemlerini hayata geçirebilmeleri için önemli bir kaynak sağlamaktadır.

\section{Dijital Çağda Dönüşen Annelik Kavramı}

Instagram en dar anlamıyla, içine daha fazla anımızı sığdırdığımız ve daha fazla kişiye daha kısa sürede ulaştırdığımız aile albümlerimizin dijital halidir. Geleneksel aile albümlerinin "özel" ve "sınırlı" olan yanı dijital albümümüzle birlikte "kamuya" açılmıştır. Takipçilerinin yorumları ve beğenileri ile etkileşimli hale gelen bu dijital albümlerimiz, dönüşmüş bir annelik anlayışını da incelememize imkân sağlamaktadır. Henüz çocuk dünyaya gelmeden çocuk ile ilgili tüm detayların görseller aracılığıyla takipçilerine sunulması çabaları, günümüz "postmodern annelik" kavramını yaratmıştır (Teke, 2014: 34). "Kamusal İnsanın Çöküşü” eserinde Sennett, kamusal alan ile birlikte aile kavramının da hızla dönüştüğüne değinmiştir (Aktaran: Dursun, 2019: 199). Whitehead ise yaptığ 1 bir araştırmada, sosyal ağlardaki annelik pratiklerinin anneliğin kendisine kamusal bir görünürlük kazandırdığını; özel yaşam ile aile yaşamının doğrudan bağlantılı olması nedeniyle anneliğin sosyal ağlar aracılığıyla kamuya açık hale geldiğini belirtmiştir (Aktaran: Duygulu, 2019: 438)

İnsanlık tarihi boyunca yaşanan toplumsal değişimler, annelik rolünde yaşanan değişimlerin itici gücü olmuştur. Fransız feminist yazar Elisabeth Badinter'in cevabını aradığ1 anneliğin içgüdüsel bir duygu mu, yoksa zamanla değişen, topluma, törelere bağlı bir tavrın sonucu mu olduğu sorunsalı henüz çözüme kavuşmamışken; kadının doğurganlığının politik bir mesele haline gelmesi değişimin ve dönüşümün hızını arttırmıştır. $\mathrm{O}$ güne değin tüm toplumsal kurumların kendi alanları dâhilinde annelik rolüne yükledikleri vazifeler, 20. yy. ile birlikte eşik atlamıştır. Kadın hareketlerinin yükselişine denk gelen bu başkaldırı, toplum tarafından tanımlanan "annelik" kavramına yeni bir soluk getirmiştir. Kadının annelik hizmetinden üretim hizmetine geçmesi onun annelik rolünün ve sorumluluklarının yeniden tanımlanması ihtiyacını doğurmuştur. "Türk Modernleşme Sürecinde Annelik Kimliğinin Kurulması" başlıklı bir çalışmada, en az iki kuşaktır kentte oturan, eğitimli, orta-üst sınıf kadınlar üzerinden annelik kimliğinin dönüşümü incelenmiştir. Araştırma, yaşlı kuşağın annelik deneyimleri üzerine daha az düşündüklerini, genç kuşağın ise "Ben nasıl bir anneyim?" sorusu üzerine sıklıkla düşündüklerini ortaya koymuştur (Aktaran: Teke, 2014:36). Bu durum çocuğun "yetişkinin küçük hali" olarak değil, özel ihtiyaçları olan bir varlık olarak kabul edilmesine denk düşmekle beraber, anneliğin kalıplaşmış rollerden çıkıp, yeniden tanımlandığını ifade etmektedir. 


\section{Annelikte Yeni Trend: Instamom}

Yaşanan tüm devrimler, ihtilaller, protestolar, isyanlar, hak talepleri doğrudan ya da dolaylı, süregelen toplumsal rollerin değişimine duyulan ihtiyaçtan doğmuştur. Ancak yaşanan çok az devrim, halihazırda yaşamakta olduğumuz Dijital Devrim kadar rolleri dönüştürmüştür. Dijital dünyanın değiştirici ve dönüştürücü gücü, tarihin hiçbir döneminde olmadığı kadar toplumları etkilemiş, onları değiştirmiştir. Dünya her an dijitalleşmekte, dijitalleşen her şey her an değişmektedir. Tam da bu noktada dijitalleşen iletişim ağlarına dâhil olmak isteyen yeni nesil anneler, anneliği sayısal dünyanın dokusuna dönüştürerek kendilerine yeni bir var olma alanı yaratmıştır.

Evrensel bir tanımı olmamakla birlikte önceleri çocuğun fiziksel, psikolojik gelişimi için gerekli şartları oluşturarak onun güvenliğini sağlamak olan annelik kavramı, şimdilerde sosyal ağlarla birlikte kendine yeni anlamlar katmıştır. Geleneksel annelik kavramı günümüz anneleri için hala geçerli bir kavram olsa da buna ek olarak sosyal ağlarda var olmak anneliğin dijitalleşen yanını temsil etmektedir. Toplumdan topluma, kuşaktan kuşağa değişen çocuk yetiştirme ritüelleri ise sosyal ağlarla birlikte görünürlük kazanmıştır. Sosyal ağlar içerisinde Instagram ise, görselliği ön plana çıkaran yapısı sayesinde yeni nesil annelerin "Instamom" kavramını var ettiği bir alan haline gelmiştir. Instamom, "Instagram" ve "mother" kelimelerinin birleşiminden meydana gelen ve Instagram'da, çocuklarının günlük yaşantılarını, sağlık durumlarını, beğenilerini, nefretlerini, kendi annelik tecrübelerini aktaran anneleri tanımlamaktadır.

Instamom'lar, fotoğraflarını dileyen herkesin görebileceği şekilde hesaplarını kilitlemeden kullanmakta ve çocukları ile ilgili günde birden fazla fotoğraf ve video paylaşmaktadır. Daniel ve arkadaşları (2012) tarafından yapılan bir araştırmada, ortalama 8 aylık bebeği olan bir anne, günün ortalama 3 saatini sosyal ağlarda geçirirken; günlük ortalama 8 saatini ise çocuğuna ayırmaktadır (Aktaran: Çimke vd., 2018: 263). Anneler günlük tutmak, ailesi ve arkadaşlarıyla iletişim kurarak izolasyon hissini aşmak, annelik duygusunun sevincini paylaşmak, çevrimiçi bir topluluğun üyesi olmak, yazmanın ve paylaşmanın verdiği motivasyonu hissetmek gibi sebeplerle çocuklarının fotoğraflarını yayımlamaktadır (Parmaksız, 2012: 128). Ebeveynler aynı zamanda sosyal ağlarda çocuklarına ait görselleri kullanarak ticari kaygıyla, diğer ebeveynlere bilgi verme amacıyla ya da yalnızca hoş vakit geçirmek için paylaşım yapmaktadır (Erişir ve Erişir, 2018: 51). Bununla birlikte birçok kadın giderek artan oranda sosyal ağlardaki ebeveynleri rol model almaktadır. Çünkü buralardan elde edecekleri deneyimi ve bilgiyi uzmanlardan alacakları kuru ve esnek olmayan tavsiyelere tercih etmektedir (Aktaran: Whitehead, 2014: 130).

Michigan Üniversitesi tarafindan 2014 y1lında yapılan "Sosyal Medyada Ebeveynler" başlıklı çalışmada annelerin yaklaşık yüzde 56'sının çocuklarının sağlıkları ya da kendi annelikleri ile ilgili konuları sosyal medyada paylaştıkları saptanmıştır. Yine aynı araştırmada, sosyal medya kullanan annelerin yüzde 74'ü diğer annelerin çocukları ile ilgili çok fazla bilgi paylaştığını, yüzde 56'sı çocukları ile ilgili ileride utanç duyacağı bilgileri paylaştığını, yüzde 51'i çocuğun konumunun tespit edilmesine imkân sağlayan paylaşımlar yaptıklarını, yüzde 27'si ise çocuğunun mahrem fotoğraflarını paylaştığını 
bildirmiştir (National Poll on Children's Health, 2015: 1-2). Family Online Safety Institute tarafından çocuklarının yaşları 6 ile 17 arasında değişen 589 ebeveyn ile görüşülerek yapılan bir başka araştırmada, sosyal medya hesabı olan ailelerin sadece yüzde 19'u yaptıkları paylaşımlardan çocuklarının ileride utanç duyabileceğini düşündüklerini söylemiştir (Family Online Safety Institute, 2015: 22). AVG Teknoloji tarafından 2010 yılında yapılan bir araştırmaya göre ise çocuklar 6 aylıkken dijital kimlik kazanmaktadır (AVG Technologies, 2010: 1).

Sosyal medya annelere, annelik deneyimlerini paylaşmaları için eşsiz bir firsat sunarken aynı zamanda annelik halinden duydukları mutluluğu çoğaltmalarına da imkân vermektedir. Çocuk ve Haklarını Koruma Platformu tarafından yapılan bir araştırmada ebeveynlerin yüzde 83'ü çocuklarının fotoğraflarını paylaşmaktan mutluluk duyduklarını, yüzde 26'sı ise çocukları ile ilgili yapılan yorumların hoşuna gittiğini ifade etmiştir (Çocuk ve Haklarını Koruma Platformu, 2017: 28). İngiltere'de 2 bin ebeveynin katılımıyla yapılan bir araştırmaya göre ise ebeveynler çocukları ile ilgili yılda yaklaşık 195 fotoğraf paylaşmakta ve paylaşımlarının gizliliği konusunda endişe duymamaktadır. Ankete katılan ebeveynlerin yüzde 46'sı sosyal ağlarda bir ya da iki kez gizlilik ayarlarını kontrol etmiş, yüzde $17^{\prime}$ 'si ise hiçbir zaman kontrol etmediği bildirilmiştir (Aktaran Çimke vd., 2018: 264).

Toplum tarafından anneliğe atfedilen kutsallığın, kadının kendi varlığından ya da kendi var ettiği tüm kimliklerden daha üstün kabul edilmesi, kutsal annelik mitinin arkasına sığınılarak yapılan birçok eylemi meşru kılmaktadır. Çocuk sahibi kadınlar, annelik üzerinden inşa ettikleri benliklerini topluma onaylatmak, onaylanmış kimliği üzerinden haz duymak adına çocuğunun bir birey olarak varlığını hiçe sayabilmektedir. Çocuğun kişilik haklarını, mahremiyetini ve unutulma hakkını çiğneyen sosyal medya paylaşımları, ileride ciddi hukuki sorunlara da gebedir.

\section{Araştırmanın Amacı}

Sosyal medya, yaşam serüvenimiz içerisinde kısa bir geçmişe sahiptir. Bu yeni iletişim kanalının yarattığ 1 akımlar, fenomenler, uygulamalar ise henüz tanıştığımız olgulardır. Durum böyle iken sosyal ağların yarattı̆̆ 1 dönüşümlerin etkileri ise tam anlamıyla ortaya konulamamıştır. Sosyal ağların kısa vadede yarattığı etkiler, halihazırda yaşam döngümüze dâhil olmuştur. Oysa uzun vadede yaşatacağı derin dönüşümler, tartışılmakta ve araştırılmaktadır. Bu doğrultuda yürütülen çalışmanın başlıca amacı, Instagram annelerinin sosyal medyada çocukların özel yaşamın gizliliği, unutulma ya da mahremiyet ile ilgili hakkını ihlal edecek ve çocuk istismarına neden olacak paylaşımlarının analizini yapmak ve konuyla ilgili farkındalık yaratarak yasa koyucular, ilgili kurumlar ve ebeveynler için bilimsel bir rehber ortaya koymaktır.

\section{Araştırmanın Yöntemi}

Bu çalışma ile sosyal medya ağları içerisinde yer alan Intagram'ın, yeni akımı olan "Instagram Anneleri (Instamom)" incelenecektir. Instagram annelerinin günlük paylaşım 
pratiği içerisinde çocuk haklarını ihlal edecek, çocuğun başkaları tarafından istismar edilmesine neden olabilecek ve güvenliğini tehlikeye düşürecek paylaşımların analizi yapılacaktır. Bu kapsamda kendini “Instagram Annesi” olarak tanımlayıp tanımlamadığına bakılmaksızın, takipçi sayısı 100 binin üzerinde olan ve çocukları ile ilgili sık paylaşım yapan, popüler 5 Instagram hesabının kullanıcısı;

- Anne P

- Anne Z

- Anne S

- Anne E ve

- Anne M'nin,

Şubat 2018-Şubat 2019 tarihleri arasında yaptığ ve içerisinde çocuğun yer aldığı toplam 1.591 paylaşım incelenerek, aşağıdaki sorulara cevap aranacaktır.

S.1. Instagram hesabı gizli bir hesap mı?

S.2. Takipçi sayısı kişinin yakın çevresini oluşturamayacak kadar fazla mı?

S.3. Çocuk odaklı günlük görsel/video paylaşım sıklığı nedir?

S.4. Paylaşılan görseller/videolar çocuğun özel yaşamın gizliliği hakkını ihlal ediyor mu?

$\mathrm{Bu}$ sorular kapsamında, içeriğinde çocuk olan paylaşımlar baz alınarak aşağıdaki durumlar tespit edilecektir.

- Çıplak ya da yarı çıplak görseller/videolar, videolar1,

- Çocuğun uyurken, ağlarken, yemek yerken, öğrenme aşamalarında görselleri/

- Çocuğun güvenli alanlarında çekilen görselleri/videoları var mı?

Sosyal medyada çocuk hakları ihlali ve çocuk istismarının Instagram anneleri üzerinden incelendiği bu çalışmada, netnografik araştırma yöntemi kullanılacaktır. İletişimin dijitalleşmesi ile etnografik araştırmaların internet üzerinden gerçekleştirildiği bir yöntem olan netnografik araştırma yöntemi, bilgisayar tabanlı ortamlarda bireyleri, grupları, toplumları incelemek; eylemlerin ve söylemlerin bağlamsal kodlarını gözlemlemek için kullanılan bir yöntemdir (Kozinets, 2010) Netnografinin araştırma alanı bilgisayar ortamında var olan resim, video, metin, sembol, dil ya da davranış biçimleridir. Toplumsal olayları anlamada iç görüden faydalanan bu yöntem, rakamların satır aralarını yorumlayarak çözüm odaklı bir araştırma sunar (Özbölük, Dursun, 2015: 228). 


\section{Araştırma Bulguları}

$\mathrm{Bu}$ çalışmada takipçi sayısı 100 binin üzerinde olan ve çocukları ile ilgili sık paylaşım yapan, popüler 5 Instagram hesabının paylaşımlar, içeriği daha önce belirlenen başlıklar altında değerlendirilmiştir. Instagram hesabı incelenen annelerin çocuklarının tamamının yaş aralığ $0-5$ yaştır.

\section{Instagram hesabı gizli bir hesap mı?}

Sosyal medya platformlarında, fotoğrafların ya da videoların sadece onaylanmış takipçiler tarafından görülebileceği hesaplar, gizli hesap olarak adlandırılmaktadır. Sosyal ağlarda paylaşılan gönderiler, bu ağlardaki gizlilik ayarlarına bağlı olarak herkese görünür halde olabilir. Instagram uygulamasında gönderileri gizli yapmak ya da açık hale getirmek bir seçimdir. Bu durumda eklenen tüm iletiler, ya sadece yakın çevre tarafından görünecektir ya da dünyanın herhangi bir yerinde herhangi birinin cebine girecek kadar kamusallaşacaktır. Bununla birlikte paylaşılan gönderilere "HasTag (\#)" yani "konu etiketi” ile anahtar sözcük eklendiği durumlarda ise, dünya üzerinde bu anahtar sözcüğü içeren bütün paylaşımlar zaman sırasına göre sıralanmaktadır.

Seçilen Instagram annelerinin profilleri incelendiğinde, hiçbirinin profilinin "gizli" olmadığı tespit edilmiştir. Paylaşılan her bir fotoğraf ya da video, dileyen herkesin görebileceği bir mesafededir. Başka bir deyişle, paylaşılan her bir ileti dileyen herkesin görüp, indirip, manipüle edip, yeniden paylaşacağı bir mesafededir. Aynı zamanda fotoğraf/video altına yapılan ve iletinin daha çok kişiyle paylaşılmasına olanak sağlayan etiketleme yöntemi ile de iletiyi görenlerin sayısı takipçi sayısını aşarak milyonları bulabilmektedir. Örneklem olarak seçtiğimiz anneler, konu etiketi olarak en fazla çocuğunun ismini, yaşını içeren ya da günün önemini belirten etiketleri tercih etmektedir. Çocuğunun ismi ya da yaşı ile ilgili etiketlemeler spesifik etiketlemelerdir (\#ayşe6yaşında) ve ancak özel merak ve ilgi dahilinde bu anahtar sözcüğe tıklanarak tek bir kişi ile ilgili ve o etiketi taşıyan tüm görsellere ulaş1labilir. Bununla birlikte örneğin o günün önemini belirten etiketlemeler (\#dünyakızcocuklarıgünü) evrensel bir duruma karş11ık geldiğinden, bu etiket altında yer alan paylaşımlar daha fazla kişiye ulaşmaktadır. Aynı zamanda hesapları incelenen annelerin etiketlemelerinin büyük bir kısmını İngilizce yapmaktadır. $\mathrm{Bu}$ da paylaşılanların, dünyanın her yerinde bu özel kelimelerle ilgilenen diğer kullanıcılara ulaşmasını sağlamaktadır. Anneler oluşturdukları içerikleri en fazla "\#bebeğim, \#photooftheday, \#tbt ve \#selfie" etiketleri ile paylaşmaktadırlar. Bu etiketler 2018 yılının en fazla kullanılan etiketleri olmuştur. Dolayısıyla içeriklerin ulaştığı kişi sayısı sahip olunan takipçi sayısının oldukça üstüne çıkmaktadır.

\section{Takipçi sayısı kişinin yakın çevresini oluşturamayacak kadar fazla mı?}

Sosyal medya hesapları için takipçi sayısı, tanınır olmak için en önemli unsurdur. Kurumsal firmalar yahut "fenomen" olmak isteyenler, daha fazla kişiye ulaşmak için takipçi sayılarını çeşitli yöntemlerle arttırmanın yolunu aramaktadır. Takipçi sayısının fazla olması kurumsal firmalar için güvenilir olmaya tekabül ederken, bireysel kullanıcılar için ilginç içeriklere denk gelir. Kurumsal firmaların sayfalarını ziyaret eden kişiler önce takipçi sayılarına bakarak firmanın güvenirliğini ölçer; ne kadar takipçi varsa o kadar 
güvenilir olduğuna kanaat getirir. Bireysel kullanıcılar içinse, yine takipçi sayısının fazla olması bir önyargıya varılmasına neden olarak, içeriklere bakmadan takip etme davranışını tetikler (sosyalmarketim.com). Örneklem olarak seçilen annelerin takipçi ve takip edilen sayısı, Şubat 2019 tarihi itibariyle aşağıdaki gibidir.

Tablo 1: Annelerin takipçi, takip edilen sayısı

\begin{tabular}{|c|c|c|}
\hline Anneler & Takipçi & Takip Edilen \\
\hline Anne P & 600 bin & 1.313 \\
\hline Anne Z & 434 bin & 497 \\
\hline Anne S & 426 bin & 1.073 \\
\hline Anne E & 314 bin & 514 \\
\hline Anne M & 299 bin & 2.182 \\
\hline
\end{tabular}

Kişinin yakın çevresini yüz yüze görüştüğü, ortak bir geçmişe sahip olduğu, kalıcı ve samimi ilişkiler kurduğu ve duygusal yakınlık hissettiği kişiler oluşturur. Bu ilişkilerin temelinde karşılıklı sevgi vardır ve görece az sayıda insanı barındırır. Sosyal çevre ise, bireyin ve insan topluluklarının içinde geliştiği, öğrendiği, değiştiği ve değiştirdiğgi, yakın çevresi dışında kalan grubu temsil eder. Yakın çevre ilişkileri, güven temelinde sürekliliğini sağlayabilirken, sosyal çevrenin temelini daimi ya da geçici ortak hedefler ve ilgi alanları oluşturur.

$\mathrm{Bu}$ bilgiler 1şı̆̆ında annelerin takipçi sayısı, yakın çevreyi oluşturan çemberin dışında, yüksek bir rakama karşılık gelmektedir. Örneklemde yer alan tüm hesapların açık hesap olduğu verisinden yola çıkılarak, aynı zamanda organik (gerçek) takipçiler dışında hesabı gizlice takip edenler ile birlikte iletilerin ulaştığı insan sayısı kimi zaman milyonları bulmaktadır. Aynı zamanda kopyalanıp yeniden paylaşılan ileti, kaynak sayfa dışında paylaşan tüm sayfaların takipçilerine de ulaşmaktadır. Böylece gönderi yeniden ve yeniden üretilerek; zamanı ve sınırları aşmakta, anonimleşmektedir.

\section{Günlük görsel/video paylaşım sıklı̆̆ı nedir?}

Sosyal medya sınırsız fotoğraf, video ve metin paylaşma imkânı veren ve yine bu verileri sınırsız sürede saklama imkânı sağlayan sanal platformlar bütünüdür. Her bir sosyal ağ, kullanıcılarını içeride tutmak ve daha fazla kullanıcıya ulaşmak için sürekli kendilerini güncellemekte; bu da kullanıcılar için yeni paylaşım yapma yöntemlerini yaratmaktadır. Önceleri yalnızca profil sayfasında, sınırsız fotoğraf ve video paylaşımı için dizayn edilen Instagram, sonraları güncellenerek kendine yeni özellikler katmıştır. "Instagram Stories" adıyla 2016 yılında gelen özellik, haber akışının en üstünde yer alacak şekilde gönderi paylaşma imkânı vermektedir. Tüm bunlarla birlikte Instagram, kendi içerisinde de çeşitlenerek, kullanıcılarına sonsuz kendini ifade etme alanı sunmaktadır.

Örneklem olarak seçilen annelerin profil sayfaları incelendiğinde paylaşımlarının ağırlıklı olarak çocukları ile ilgili olduğu gözlemlenmiştir. 
Tablo 2: Annelerin belirlenen süre içerisinde çocukları ile ilgili yaptıkları paylaşım sayısı ve oranı

\begin{tabular}{|c|c|c|c|c|}
\hline Anneler & Toplam Gönderi & $\begin{array}{c}\text { Günlük Ortalama } \\
\text { Gönderi Sıklığı }\end{array}$ & $\begin{array}{c}\text { Çocuk İle İlgili } \\
\text { Gönderi }\end{array}$ & $\begin{array}{c}\text { Günlük Or- } \\
\text { talama } \\
\text { Gönderi Sıklı̆̆ }\end{array}$ \\
\hline Anne P & 201 & 0,5 & 122 & 0,3 \\
\hline Anne Z & 486 & 1,3 & 310 & 0,8 \\
\hline Anne S & 1.040 & 2,8 & 764 & 1,9 \\
\hline Anne E & 951 & 2,6 & 703 & 1 \\
\hline Anne M & 657 & 1,8 & 395 & \\
\hline
\end{tabular}

*Şubat 2018 - Şubat 2019 tarihleri arasındaki paylaşımları kapsamaktadır.

$\mathrm{Bu}$ veriler 1şı̆̆ında, Anne $\mathrm{P}$ yaklaşık 2-3 günde 1; Anne $\mathrm{Z}$ yaklaşık günde 1; Anne $S$ günde 2; Anne E yaklaşık günde 2; Anne $\mathrm{M}$ günde 1 olmak üzere çocuklarının günlük aktivitelerini içeren çeşitli paylaşımlar yapmaktadır. Bu rakamsal verilere daha önce sözü edilen "Stories" özelliği ile paylaşılan görseller/videolar dahil değildir. Kısacası paylaşım sıklığının bu denli yoğun olması çocuğunun gününün büyük bölümünün fotoğraf/ video çekimi ya da bunlar için ortamların oluşturulmasıyla geçtiğini söyleyebiliriz. Bu durum aynı zamanda çocuğun sanal-gerçek algısının bozulmasına da neden olmaktadır. Zamanının büyük bölümünü kamera karşısında geçiren çocuk, bir süre sonra sevimli, güzel, akıllı, konuşkan olmayı görev bilecek ve bu durumu içselleştirerek, istem diş1 her an en mükemmel haliyle davranmak isteyecektir. Annelerin bu kadar sık çocuk fotoğrafları paylaşmalarının nedeni olarak ise, çocuk fotoğraflarının daha fazla beğeni ve yorum alması gösterilebilir. Bu sayede artan etkileşim, beraberinde yeni takipçileri getirmektedir. Her yeni takipçi ise beğeni ve yorum sarmalını genişleterek başka yeni takipçileri içeri çekmektedir. Bu döngü her gün yeni görsellerle beslenerek, annelerin görünür olma arzularını tatmin etmektedir.

\section{Paylaşılan görseller/videolar çocuğun özel yaşamının gizliliği hakkını ihlal ediyor mu?}

Günümüzün en geçerli iletişim kurma yöntemi olarak kabul edilen sosyal ağlar, süreç içerisinde amacını ve sınırlarını aşan bir alana dönüşmüştür. Kişinin kendi benliğini sosyal ağlar üzerinden yaratma çabaları, "sanal" durumun doğası gereği gerçek dışı bir "olumluluk" halini teşvik etmektedir. Bu haliyle anneler, yeterince gerçek olan çocuğun günlük yaşam pratiklerinin halihazırdaki "sevimli” halini, kendi sanal kimliğini yaratma çabaları içinde sıklıkla kullanmaktadır.

Örneklem olarak seçilen annelerin Instagram hesapları incelendiğinde de çocuklarını, günlük hayatlarının her haliyle sosyal ağlarda var ettiklerini görebiliriz. Anneler özellikle yemek yerken, uyurken, oyun oynarken, gülerken, ağlarken, kızgınken ve üzgünken; denizde, havuzda, okulda, kreşte, parkta, bahçede kısaca her an ve her haliyle Instagram'da paylaşmaktadır. Annelerin çocukları üzerinden görünür olma arzularının belli başlı nedenleri tanınır olma, bu tanınırlık üzerinden ürün satma, kendi markasını yaratma ya da yarattığı ürün ya da markayı pazarlamaktır. 
Anne P: 600 bin takipçisi ile Instagram anneleri arasında en tanınır olanıdır. Buna rağmen toplam paylaşım sayısı ve paylaşım sıklığı diğer annelere göre nispeten azdır. 2019 yılı itibariyle 2 yaşında olan çocuğunun günlük yaşam aktivitelerini, çoğu zaman en komik, en eğlenceli haliyle sergilemektedir. Ancak gülmek ve eğlenmek eylemlerine sebep olan hallerin "görecelilik" durumu nedeniyle, paylaşımlara çocuk açısından baktığımızda tam tersine dönmektedir. Anne P'nin "komik" ve "eğlenceli” kategorisinde değerlendirilebilecek birçok paylaşımı, aslında çocuğun zaman zaman içinde bulunduğu “mutsuz" ve "agresif” ruh hallerinin yansımasıdır. İnsanın kendiliğindenliğin olan bu ruhsal durumların çocukta cereyan etmesi, birçok Instagram annesi tarafindan paylaşılmaya değer görülmektedir. Özellikle çocuk ağladığı sırada çekilen videolar ve fotoğraflar, eğlenceli görsel altı metinlerle gülünç hale getirilmektedir. Durumun sunumsal düzenlemelerle komik hale getirilmesi bir yana, temelde ağlayan bir insanın görüntülerinin milyonlara servis edilmesi, başlı başına "ahlaki" ve kimi durumlarda da "hukuki" bir sorundur. Anne P'nin birçok paylaşımında çocuğunun ağlayan hallerinin bulunması ve bu paylaşımları metinlerle eğlenceli hale getirmesi, çocuğun duygusal istismarına neden olmaktadır. Ağlamak masumdur, bu anlar insanın en mahrem zamanlarıdır. Çocuğun ağlaması her ne kadar çoğu zaman fiziksel ihtiyaçlarından da kaynaklansa, fiziksel acı çeken bir yetişkinin ağladığı andaki görüntülerini çekmek dahi büyük ahlaki problemleri beraberinde getirir. Böyle bir durumda yetişkin için geçerli olan tüm ahlaki değerler ile hukuki metinlerin çocuk için de geçerli olduğunu anımsarsak, bu tarz paylaşımların eğlenceden ziyade istismarı beraberinde getirdiğini anlayabiliriz.

Anne P'nin Instagram hesabı incelendiğinde dikkat çeken bir diğer durum ise çocuğuna lakap takması ve yine komik olduğunu düşündüğü başka bir isimle hitap etmesidir. Instagram dijital bir arşivdir. Yazılan ve kaydedilen her şey sonsuza denk sanal düzlemde var olur. Şimdiki zamanda hiçbir sorun yaratmayacak hatta masum kabul edilecek birçok şey, gelecek zamanda tüm güzellikleri yok edecek bir güce dönüşebilir. Çocuğa takılan lakap yahut komik hitap şekilleri, çocuğun yetişkinlik zamanlarında, kendi akranları tarafından sistematik bir biçimde zarar vermek amacıyla kullanılabilir. Bir diğer deyişle bir annenin sadece komik diye kendi çocuğuna taktığı sıfatlar, ileride "zorbalar" için fikir verici olacaktır ve çocuk hem akranlarının hem de ebeveynin kurbanı olacaktır. Bu durumun çocuğun öz benliğinde yaratacağı yıkım ise, anlık bir eğlencenin sonsuz kat üzerindedir.

Bununla birlikte yine birçok annenin paylaşımlarında görüleceği üzere, Anne P de sık sık çocuğunun yarı çıplak, bezli, üst kısmı çıplak ya da alt kısmı çıplak fotoğraflarını ve videolarını paylaşmaktadır. Bu durum ilk anda zararsız görünse de, daha önce de belirtildiği üzere bu hesapların tamamının gizlilik ayarları açıktır. Dolayısıyla masum ve sıradan görünen her bir görsel, kötü niyetli kişilerin elinde istismar aracı olarak kullanılabilir. Pedofili tehlikesinin yalnızca sokaklarda değil, sosyal mecrada da var olduğunu düşünürsek, art niyetsiz yapılan bu tür paylaşımlar olumsuz durumlarla sonuçlanabilmektedir. Bununla birlikte görsellerin kopyalandıktan sonra manipüle edilip çocuk pornografisi sektörüne sunulması da olasıdır. Aynı zamanda çocuklar ebeveynlerini rol model alarak, her davranışını taklit etmektedir. Bu durumda bedeninin ebeveyni tarafından teşhir edildiğini gören çocuk, bedenin mahremiyetinin kavramakta zorlanacak ve ilerleyen dönemlerde kendini teşhir etmekten sakınmayacaktır. 
Anne P, çocuğu ile ilgili paylaştığı görsellerin büyük kısmını evinde çekmektedir. Bununla birlikte dışarıdan, havuzdan, cafelerden, alış verişten kısaca çocuğun dahil olabileceği pek çok alandan fotoğraflar ve videolar bulunmaktadır.

Anne Z: 434 bin takipçisi ile Instagram'ın en popüler annelerinden olan Anne Z, bir yıl içerisinde çocuğuna ait yaklaşık 310 görsel paylaşmıştır. Bu paylaşımlara, Stories üzerinden günlük kaydedilen görseller de eklenince, çocuğun hemen her anının sosyal mecra üzerinden sergilendiği görülmektedir. Anne $Z$, çocuğu üzerinden sık sık ürün ve hizmet reklamları yapmaktadır. Özellikle çocuğun yaşına ve gelişimine uygun olmayan ürünlerin tanıtımını yaparak, çocuk üzerinden kazanç sağlamakta ve çocuğunu ticari meta olarak kullanmaktadır. Çocuğun yaşına ve kullanımına uygun olmayan ürünlerin arasında zincir marketler, alış veriş merkezleri, ev ürünleri mağazaları, cilt bakım malzemeleri, şekerli yiyecekler ve hazır içecekler vardır.

Anne $\mathrm{Z}$ ile birlikte diğer anneler de ürün tanıtımı için çocuklarını, sıklıkla kullanmaktadır. $\mathrm{Bu}$ durum, çocuğun yetişkinlerin duygularını harekete geçirme potansiyelinden kaynaklanmaktadır (Uğurlu, Uğurlu, 2017, s 20). Çocuk, saflığ1 dolayısıyla güvenilir mesaj kaynakları olarak görülmekle birlikte (Kuruoğlu, Soygüder, 2009, s 160), "yararsal, varoluşsal, eğlensel, tüketim, değeri yaratmak" amaciyla da kullanılmaktadır (Yücel, Kara'dan aktaran Uğurlu, Uğurlu, s 20). Bu durum çocuğun internet ortamında ekonomik sömürüsüne neden olmaktadır.

Anne Z'nin paylaştığı görsellerin kurgusallık oranı oldukça yüksektir. Çocuğun güvenli ortamlarında doğal olmayan bir organizasyon sonucu ortaya çıkmıştır. Bu tür ortamlar genellikle ürün tanıtımı için oluşturulmaktadır. Kimi videolarda çocuk, bu kurgusallığı hayatın bir parçasıymışçasına içselleştirerek gerekli talimatları yerine getirmektedir. Aynı zamanda Anne Z, çocuğunun kimi komik fotoğrafları ve videoları üzerine not düşerek paylaşmaktadır. Bu şekilde görüntü ve metin bir bütün halinde anlamlı ve komik bir formata dönüştürülerek, viral (bir paylaşımın hızlı bir şekilde yayılması) haline gelmektedir. Böylece kurgulanmış görseller, her daim arşivde duran birer eğlenceliğe dönüşmektedir.

Anne Z, birçok defa çocuğunun bornozlu, bikinili, mayolu, iç çamaşırlı, alt kısmı çıplak fotoğraflarını paylaşmıştır. Özellikle yaz mevsiminde havuzda ya da denizde görselleri de bulunmaktadır. Sosyal medya, tüm iletişim kurma biçimlerimizi değiştiren bir devrimdir. Dijitalleşen iletişim biçimi hayatlarımızı kolaylaştırırken, önceleri nispeten uzak tehlikeleri de yakınımıza getirmiştir. Yüzyılımızda, mağdurun çocuk olduğu ve suç teşkil eden davranışların en ürkütücüsü pedofili, sosyal medya üzerinden rahat hareket etme alanı yakalamıştır. Pedofiller, sosyal ağlar üzerinden kurbanlarını tespit ederek onlarla iletişime geçmekte, sevgi göstererek güvenlerini kazanmaktadır. Bu saatten sonra çocuk istenilen şekilde yönlendirilmektedir. $\mathrm{Bu}$ durum, hesabın kullanıcısının çocuk olduğu durumlarda pedofilin kullandığı yöntemdir. Bir diğer kurbana ulaşma yöntemi ise, ebeveynlerin sosyal ağlar üzerinden paylaştığı fotoğraflardır. Her ne kadar birçok ebeveyn sosyal medya hesaplarında sadece yakınlarının bulunduğunu söylese de, birçok çalışma çocuk cinsel istismarının yakın çevreden geldiğini ortaya çıkarmıştır. Böyle bir durumda, ebeveynin paylaştığ 1 ve çocuğun mahrem bölgelerinin açıkta bırakıldığ 1 fotoğraflar, çocuklara karşı cinsel isteği bulunan kişilerde uyarıcı bir etki yaratmaktadır. 
$\mathrm{Bu}$ tür davranışlara karşı gelişen tepkiler, toplumsal yaşam içerisinde kadına giyimi ve bedeni üzerinden yapılan bir baskının benzeri değil; bizzat çocuğun karar verme yetisinin bulunmayışından kaynaklanan mahremiyet hakkının ihlalinin önlenmesi çabalarıdır.

Anne Z, çocuğuna ait görselleri genel olarak ev ortamında çekmektedir. Bununla birlikte yatağında uyurken, odasında oynarken görüntülenmiş görselleri de bulunmaktadır.

Anne S: Yarım milyona yakın takipçisi ile en dikkat çeken Instagram annelerinden biridir. Çocuğunun doğduğu andan itibaren hemen her anını kaydedip takipçileri ile paylaşan Anne $\mathrm{S}$, anne kimliği ile yarattığı değeri sıklıkla reklam iş birliklerinde kullanmaktadır. Anne S, Instagram hesabında çocuğunu kullanarak sık sık ürün ve reklam tanıtımı yapmaktadır. Çocuğunu kullandığ 1 tanıtımların birçoğunda ürün, çocuğun yaşına ve kullanımına uygun değildir. Bu ürünler arasında mücevherat, iç giyim, mobilya ve ayakkabı vardır. Ancak Anne S'nin hesabında dikkat çeken bir diğer durum, çocuğunu yaptığı reklamlarda direkt kullanmadığı durumlarda, onu bir obje ya da dekor gibi, tanıtımın içerisine dâhil etmesidir. Yani ürün ya da marka tanıtımında çocuğu doğrudan kullanmamakta, ancak çocuğunun tanınırlığını dolayısıyla yarattığı değeri, marka ya da ürünü pazarlarken kullanmaktadır. Bu durum, çocuğun ilk önce yoğun paylaşım ve etkileşim sonucu değeri olan bir markaya dönüştürülmesi, daha sonra ise yaratılan bu değer üzerinden başka marka ve ürünlerin tanıtımının yapılması çabalarının sonucudur. Her iki durumda da çocuk, pazarlama stratejisi olarak kullanmaktadır.

Bazı videolarında Anne S'nin çocuğu, dışarıda tanımadığı insanlar tarafından durdurulup sevilmektedir. Videodan anlaşıldığı üzere bu insanlar Anne S'nin hesabını takip edip, çocuğu tanıyanlardır. Videoda çocuğun bu davranışa anlam veremediği görülmektedir. Ancak ilk anda çocuk için anlamsız gelen bu davranış, daha sonra doğal hale gelecektir. Bu durumun zamanla çocukta narsist kişilik bozukluğu ya da aşırı ilgiye ve sevgiye karşı bağımlılık yaratma ihtimalini doğurmaktadır.

Anne S de diğer anneler gibi çocuğunun bedenini teşhir edecek görseller paylaşmaktadır. Örneğin bir paylaşımda çocuk, küvetin içerisinde banyo ederken görüntülenmiştir. Bununla birlikte yaz aylarında sık sık mayolu ve bikini fotoğraflarını paylaşmakta; zaman zaman da alt kısmı çıplak ya da bezli fotoğraflarına yer vermektedir. Çocuğun bazı fotoğraflarında ise bornozlu olduğu görülmektedir. Anne S, çocuğuna ait görselleri genel olarak ev ortamında çekmektedir. Bununla birlikte banyoda, odasında ya da parkta oynarken görüntülenmiş görselleri de bulunmaktadır.

Anne E: 2019 yılı Şubat ayı itibariyle 314 bin takipçisi bulunan Anne E, çocuk istismarına neden olacak paylaşımları ile dikkat çekmektedir. Anne E, sayfasında sık sık ürün ve marka tanıtımı yapmaktadır. Bu tanıtımlarda sıklıkla çocuğunu kullanmaktadır. Anne E, çocuğunu kullandığı reklamların büyük çoğunluğunu çocuk kıyafeti tanıtımları oluşturmaktadır. Ticari kazanç elde etmek isteyen birçok marka ürettiği feminen çocuk kıyafetlerini hedef kitlelerine sunmak için yine çocuklardan faydalanmaktadır. Anne E'nin sayfası incelendiğinde feminen çocuk kıyafetleri pazarlayan firmaların reklamlarını sıklıkla yaptığı ve bu tanıtımlarda çocuğunu kullandığ1 görülmektedir. Aşırı süslü, dar, dantelli, kadınsı kıvrımları ve desenleri bulunan; çanta ve kemerle bütünlediği kıyafetleri çocuğuna giydiren Anne E, bu görüntüleri milyonların nazarına sunmaktadır. Aynı 
zamanda çocuğun, fotoğraf çekimleri sırasında yine yetişkin pozları verdiği görülmektedir. Anne E, bu nedenle diğer anneler tarafindan sık sık eleştirilmektedir. Ancak profilinde diğer annelere nazaran birçok farklı çocuk kıyafeti markası ile iş birliği içinde olduğu görülmektedir. Bu durumdan, çocuğunu teşhir etmek yoluyla daha fazla dikkat çektiğine ve bu sayede daha fazla markadan teklif aldığı sonucuna varabiliriz. A n n e n i n ürün tanıtımı yaptığı görsellerin altına yapılan yorumlar incelendiğinde, zaman zaman çocuğun fotoğraflarının başka sitelerde de kullanıldığı ile ilgili bilgiler de verilmektedir. Kişisel içeriklerin ve görsellerin kopyalanarak farklı amaçlarla kullanılması, sosyal medya kullanımın yaygınlaşması ile hayatımıza giren bir sorundur. Söz konusu çocuk olduğunda, fotoğrafların ve videoların başka alanlarda kullanılmak üzere kaynak sayfadan kopyalanarak yeniden üretilmesi, daha ciddi problemleri beraberinde getirmektedir. Miyarlarca kullanıcısı ile Instagram, fotoğrafların ve kişisel verilen çalınması ile ilgili henüz somut bir girişimde bulunmamıştır. Hesap ayarının gizli olması dışında, bu soruna teknik olarak kalıcı bir çözüm bulunması şimdilik mümkün değildir. Bu nedenle paylaşılan her bir görsel, uygulamadan ziyade kullanıcının sorumluluğuna bırakılmıştır. Çocuğun velayet hakkının sahibi olan ebeveyn, onun her türlü korunması ile ilgili tedbirleri almakla yükümlüdür. Bu noktada anne-babanın sorumluluğu siber alanda da devam etmektedir.

İnternet, kimi zaman gerçek yaşamdan bağımsız bir simülasyon olarak görülmekte; internetin sanallığı bu alanda var olan hiçbir durumun gerçek dünyada karşılığının olamayacağı yanılsamasını yaratmaktadır. Oysa dijital dünya, gerçek ile sanal arasında bir adım mesafededir. Sanal alanda kazanılan dostluklar, düşmanlıklar, maddi kazançlar; gerçekleşen ihlaller, istismarlar ya da yapılan suçlar hepsi gerçek dünyaya aittir. Bu nedenle, örneğin çocuğunu çocuk istismarına karşı korumak ve ona yaşına uygun cinsel eğitim vermekle sorumlu olan ebeveyn, söz konusu sosyal medya olduğunda bu sorumluluğunu internetin gerçek dişılığına kurban etmemelidir.

Anne E, tanıtımını yaptığı çocuk plaj giyim ürünlerinde çocuğunu model olarak kullanmaktadır. Feminen mayo ya da bikini giydirdiği çocuğuna yine feminen pozlar verdirmekte ve bu yolla satışını arttırmayı hedeflemektedir. Bu tür görsellerde çifte istismar oluşmakta; çocuk ticari bir meta olarak kullanırken aynı zamanda cinsel istismara neden olabilecek görüntüleri internet yoluyla yayımlanmaktadır. Bununla birlikte Anne E hesabında, çocuğunun mayolu ve bikinili görsellerini paylaşmakta, hamamda ya da bornozlu fotoğraflarına ve videolarına da yer vermektedir.

Anne E'nin hak ihlaline neden olacak bir diğer davranışı ise, çocuğunun doktor muayenesi sırasında videolarını çekmesi ve bunu takipçilerine sunmasıdır. Burada ihlal anne ve doktor eliyle gerçekleştirilmektedir. Anne, çocuğunun hemen hemen yarı çıplak haldeki muayene videolarını çekip yayımlayarak, doktor ise kendi görev alanında buna müsaade ederek hastanın mahremiyet hakkını ihlal etmektedir. Sağlık Bakanlığg tarafından yayımlanan Hasta Hakları Yönetmeliği'nin 21. maddesinde "Hastanın, mahremiyetine sayg1 gösterilmesi esastır" diyerek, "teşhisin, tedavinin ve hasta ile doğrudan teması gerektiren diğer işlemlerin makul bir gizlilik ortamında gerçekleştirilmesi” gerektiğini belirtmiştir. Ancak Anne E, diğer annelerden de tepki alan bu paylaşımlarını zaman zaman tekrarlamakta, çocuğunun hastalığı ile ilgili detayları vermektedir. 
Anne E de diğer anneler gibi çocuğunun odasında, evinde ya da hastanede çektiği görselleri paylaşmakta; paylaşımların bir kısmında çocuk yemek yemekte ya da uyumaktadır. Yani Anne E, çocuğunun günlük rutini arasında bulunan her eylemi görselleştirmekte ve bunu takipçilerine sunmaktadır. Özellikle iştahı açık olan çocuğunun yemek yediği videolarını görece komik metinlerle süsleyerek, ileride çocuğunun utanacağ1 ya da akran zorbalığına uğrayacağı bir kurgu içerisinde milyonlara yayımlamaktadır.

Anne M: 299 bin takipçisi vardır. Belirlenen bir yıllık süreç içerisinde yaptığ1 paylaşımların yarısından fazlası çocuğunun fotoğrafları ve videolarıdır. Bu fotoğraf ve videoların hemen hepsinde tanıtım ve ürün reklamları yapmaktadır. Anne M aynı zamanda kendi yarattığı çocuk giyim markasını yine farklı bir Instagram hesabından satışa sunmakta; bu hesapta da yine çocuğunu ürün tanıtımlarında kullanmaktadır.

Reklamcılık sektörü, pazarladığı ürüne olan güveni arttırmak ve dolayısıyla satış hedeflerine ulaşmak için sıklıkla çocuğu kullanmaktadır. Aynı zamanda çocuk annede "korku, sevgi, gurur, neşe ve utanç duyguları uyandırmak için ve sağlık, ev idaresi gibi konularına ilişkin anneye hitap etmeyi kolaylaştırdığı için" çocuk reklamcılık faaliyetlerinde yer almaktadır. (Uğurlu, Uğurlu, 2017, s 19-20). Sosyal ağlar içerisinde Instagram, görselliği ile ön plana çıtı̆̆ından dolayı pazarlama faaliyetleri için oldukça uygun bir mecradır. Bir ürün ya da markanın tanıtımı o markaya ait bir hesap üzerinden yapılabileceği gibi, son yıllarda hayatımıza dahil olan ve ürün hakkındaki deneyimlerini takipçileri ile paylaşan "Influencer" yoluyla da yapılabilmektedir. Influencer, sahip olduğu yüksek takipçi sayısı ve dolayısıyla elde ettiği popülerliği ile ürün ve markayı sosyal medya hesabı üzerinden tanıtan kişilere verilen addır. Influencer, ilk etapta belirli bir hedef ve amaç için hesabını oluşturmakta daha sonra elde ettiği popülerlik sayesinde ürün ve marka tanıtımı yapmaktadır. Bu noktada Instagram anneliği, popüler olmak ve dolayısıyla satış yapabilmek için en etkili çıkış noktasıdır. Çünkü çocuk daha önce de bahsedildiği üzere, özellikle kadınların satın alma davranışını etkileyen en önemli unsurdur. Anne M'de tüm bu tüm bu gerçeklerden hareketle çocuğunu tanıtımını yaptığı ürün ve markanın yahut kendi yarattığı markanın tanıtımında kullanmaktadır.

Anne M'nin hesabı incelendiğinde son bir yıl içerisinde çocuğunu 140 defa reklam ya da ürün tanıtımında kullanmıştır. Yani hemen her 2,6 günde bir, pazarlama amaçlı çocuğun görseli paylaşılmıştır. Bu görseller kimi zaman tek bir markanın tekrarlayan tanıtımlarını içermektedir. Kimi paylaşımlarda çocuk, tanıtımın bilincinde olarak eyleme destek vermekte; kimi paylaşımlarda ise çocuk habersiz bir şekilde tanıtıma dâhil edilmektedir. Çocuğun bu kadar sık tanıtım faaliyetlerine dâhil edilmesi, arka planda harcanan emeğin ve zamanın fazlalığı da göz önüne alındığında, onun ekonomik sömürüsünü gündeme getirmektedir. Çocuğun pazarlama faaliyetleri ile birlikte gerçeklik algısının bozulabileceği gibi, yaşının doğal getirisi olan eylemlerden uzak kalmasına da neden olabilmektedir.

Anne E, hesabında çocuğunun çıplak, yarı çıplak, mayolu ya da bikinili fotoğraflarını paylaşmamakta; havuzda ya da denizde paylaştığı görsellerde, çocuğunun bedenini herhangi bir obje ile kamufle ettiği gözlemlenmektedir. 


\section{Tartışma ve Sonuç}

Dünyada çocuk istismarı ve çocuk hakları ihlali her geçen gün daha vahim boyutlara ulaşmaktadır. Savaşların, yıkımların, yoksulluğun ve eğitimsizliğin bir sonucu olarak ortaya çıkan bu durum, her yıl milyonlarca çocuğu etkilemektedir. Çocuk hakları, 1989 Birleşmiş Milletler Çocuk Haklarına Dair Sözleşme ile güvence altına alınmış olsa da çocuklar günümüzde hala en dezavantajı konumdadır. Çocukların savunmasız bir konumda yer alması onları hak ihlallerine ve istismara daha açık hale getirmektedir.

İçinde çocuğun olduğu paylaşımların, daha fazla beğeni ve takipçi aldığı bir gerçektir. Bu nedenle çocuklarının fotoğrafını paylaşarak takipçisini sayısını arttırmak giderek daha yaygın bir hal almıştır. Çocukluğun halihazırda doğasında var olan sevimliliğinin yanına bir de çocuk çıplaklığı eklendiğinde, sıradan bir fotoğraf dahi kötü niyetle kullanılacak bir araca dönüşebilmektedir. Böyle bir durumda, sosyal medya hesabının kilitli olması yani sadece yakın çevrenin paylaşımına açık olması, yaşanabilecek olumsuzlukların engellenebilmesi için yeterli değildir. Yapılan pek çok araştırma, pedofili hastalarının kurbanlarını yakın çevrelerinden seçtiklerini ortaya koymuştur.

Dijital paylaşma eyleminin sorun yaratan yanı, paylaşımın sıklığında ve içeriğindedir. Günümüzde pek çok anne, çocuğunun mayolu ya da bikinili veya banyo yaparken çıplak fotoğraflarını, hasta hallerini, çocuğun sorunlu davranışlarını ve çocuğu hakkındaki özel bilgileri kimi zaman kendi hesabı altında kimi zaman da çocuğu adına açtığı hesaplarda paylaşmaktadır. Kimi anneler bu paylaşımları masumane görürken, kimileri ün kazanmak istemekte, kimileri ise takipçi sayısını arttırarak reklam verenlerin dikkatini çekmeyi hedeflemektedir. Her ne sebeple olursa olsun merkezinde bir çocuk bulunan ancak çocuğun dünyasına inememiş ve bir yetişkinin değer yargıları ile gerçekleştirilen her tür eylem, mutlaka sununda büyük riskleri de beraberinde getirmektedir. Ancak çocuk odaklı tutumlar ile çocuk çevrimiçi risklerden korunabilir.

Çocuk hakları kavramı, çocuğun yetişkin sınıfından çıkarılıp kendi başına bir varlık olarak ele alınmasından itibaren daha sık telaffuz edilen bir kavram olmaya başlamıştır. Çocuk hakları ihlali ve çocuk istismarı, çocuğun cinsel kimliğinden bağımsız olarak var olan, dini, etnik, coğrafi, ekonomik yahut kültürel öğelerin de üzerinde, evrensel bir sorundur. Alınan tüm yasal önlemlere rağmen çocuk üzerine çalışmalar yapan sivil toplum kuruluşları, kamu kurumları ve araştırma gurupları çocuk hakları ihlali ve istismarının dünya genelinde yaygınlığı üzerine çeşitli raporlar ortaya koymaktadır.

Sosyal medya, dijital teknolojinin hayatlarımıza dahil ettiği devasa dönüşümün belki de en önemli parçasıdır. Yaklaşık son 20 yıldır teoride iletişim kurmak, pratikte hayatımız ile ilgili gelişmeleri paylaşmak ve başkalarının hayatlarını takip etmek için kullandığımız bir mecradır. Bu yoğun "dikizleme" pratiğinin getirdiği bir diğer sonuç ise, çocuğun sanal dünyada görünürlügünün artmasıdır. Gündelik hayatın sıradan bir eylemi haline gelen Instagram paylaşımları, belki de en çok çocuğun toplumsal alandaki varlığını dönüştürmüştür. Çocuk artık yalnızca büyümesi ve toplumsal hayata karışması için ihtiyaçlarını karşılamakla yükümlü olduğumuz bir varlık değil; aynı zamanda bu ihtiyaçların karşılanması ile ihtiyaçların karşılanması aşamalarının diğerleri ile paylaşılması arasında, ebeveynlik pratiklerinin yarıştırıldığı bir alanın öznesi haline gelmiştir. 
Sosyal medya her ne kadar günlük hayatın normal bir rutini haline gelse de, günlük eylemlerin sanal dünyada bu denli görünür olması bu normalliği kırmaktadır. Annelerin çocuklarının her anını tanımadığı binlere, hatta milyonlara sunması "etik" sorunların dışında "hukuki" problemleri de gündeme getirmektedir. Bu noktada Instagram anneleri olarak da bilinen ve kişisel hesapları üzerinden sık sık çocuğunun özel yaşamını paylaşan anneler, çocuk haklarını ihlal etmekte ve çocuğunu çeşitli biçimlerde istismar etmektedir.

İncelenen her 5 annenin hesabında da çeşitli biçimlerde çocuk haklarının ihlal edildiği ve çocuğun istismar edildiği görülmektedir. Herhangi bir hesapta çocuk istismarına neden olacak bir paylaşımın bulunmaması durumunda dahi, çocuğun özel yaşamının kamusal hale getirilmesi "unutulma hakkının" ihlaline neden olmaktadır. Çocuğun izni alınmadan paylaşılan her bir görsel, video, bilgi, detay çocuğun ilerleyen yaşlarında rahatsızlık duyabileceği bir durum yaratabilir. İzni alınmış olsa dahi henüz mahremiyet bilinci gelişmemiş bir bireyde, kimliğin milyonlara ifşası özel yaşamın gizliliğini ihlal etmektedir. Bu özel bilgilerin yetişkinlik döneminde çocuğun akranları, okul ya da iş arkadaşları tarafından manipüle edilerek kullanılması ve siber zorbalığa maruz kalması olasıdır. Bununla birlikte bu paylaşımlar, çocuğun ebeveyni tarafından yaratılmış dijital kimliğinin, yetişkinlik döneminde kendi kendine var edeceği gerçek kimliğinin önüne geçmesine neden olacaktır.

Araştırma kapsamında incelenen annelerin tamamının hesabı "açık" hesaptır. Böylece paylaşılan her bir fotoğraf, video ve bilgi dileyen herkesin erişimine açıtır. Ayrıca anneler etiketleme yöntemiyle paylaşımlarının ulaştığı kişi sayısını artırmaktadır. Bununla birlikte annelerin takipçi sayısı yakın çevresini oluşturamayacak kadar fazladır. Buna organik takipçiler dışında hesabı gizlice takip edenler de dâhil edildiğinde, iletilerin ulaştığı insan sayısı kimi zaman milyonları bulmaktadır. Böylece çocuk ile ilgili paylaşılan herhangi bir fotoğraf, video ya da bilgi yeniden ve yeniden üretilerek; zamanı ve sınırları aşmakta ve kamusallaşmaktadır. Örneklem olarak seçilen annelerin profil sayfaları incelendiğinde çocuğun günlük aktivitelerine dair çok sayıda görsel paylaştığı gözlemlenmiştir. Çocuğun günlük yaşamın her an sosyal medya ağlarında görünür kılınması, çocuğun özel yaşamının ihlaline neden olmaktadır. Bununla beraber çocuğun günün büyük bölümünü akıllı telefon karşısında geçirmesi, sanal-gerçek algısının bozulmasına da neden olabilmektedir. Anneler özellikle yemek yerken, uyurken, oyun oynarken, gülerken, ağlarken, kızgınken ve üzgünken; denizde, havuzda, okulda, kreşte, parkta, bahçede kısaca çocuğunun her halini, her yerde ve tüm duygusal tepkileri ile sosyal ağlar üzerinden paylaşmaktadır. Annelerin bu denli sık paylaşım yapmaları "görünür olma" arzularından kaynaklanmaktadır. Bu sayede ürün satmakta, kendi markalarını yaratmakta ya da yarattığı ürün ya da markaları pazarlayabilmektedirler. Ancak dijital dünyada oluşturulan "ayak izleri" sonsuz süre burada kalacağı için, bir takım hak ihlallerini de gündeme getirmektedir. İnternet ortamında her bilginin, her görüntünün kaydedilebileceği ve yeniden üretilebileceği düşünüldüğünde, annenin çocuğu ile ilgili yapacağı her yayın, onun kişisel haklarına müdahale ve unutulma hakkının ihlali ile sonuçlanmaktadır. 


\section{Öneriler}

Sosyal medya denetlenebilirliği sınırlı olduğundan, çevrimiçi riskleri arttırmaktadır. UNICEF "Hiçbir çocuk çevrimiçi riskler karşısında tam güvende değildir. Zorbalar, cinsel suç işleyenler; insan tacirleri ve çocuklara zarar verecek kişiler en güç durumdaki çocuklara ulaşma açısından bugünkü kolaylığ 1 başka hiçbir dönemde yakalamamıştır (UNICEF, 2017, s 21)" diyerek, internet ortamının istismarcılara sınırsız bir hareket alanı sağladığını belirtmiştir. Özellikle sosyal ağlarda yaşanan istismar vakaları, ancak istismar gerçekleştikten sonra kamuoyuna yansımakta ve suçlular cezalandırılmaktadır. Aynı zamanda dijital teknoloji ile birlikte, tarihin hiçbir döneminde olmadığı kadar kişisel haklar ihlal edilmektedir. Tüm bu ihlal ve istismarın merkezinde çocuk bulunduğunda, bir takım önlemlerin alınması özellikle zaruridir.

Sosyal medyada çocuk hakları ihlali ve istismarının önüne geçilebilmesi için öncelikle ebeveynler bilinçlendirilmelidir. Araştırmamıza konu olan sosyal medya anneleri, bu bilinçlendirme çalışmalarının merkezine konmalıdır. Çünkü anneler, araştırma bulguları kısmında yer alan eylemleri çoğu zaman bilinçsizce gerçekleştirmektedir. Bu nedenle annelere ulaşmak, alınacak önlemlerin ilki olmalıdır. Bu kapsamda belirlenecek pilot okullarda;

-Dünyada ve Türkiye'de Çocuk Hakları ile İlgili Mevzuat

-Özel Yaşamın Gizliliği Hakkı

-Unutulma Hakkı

-Sosyal medyada çocuk haklarının hangi biçimlerde ihlal edildiği

-Sosyal medya paylaşımlarının neden olabileceği istismar türleri

-Hangi tür paylaşımların kabul edilebilir olduğu

-Hangi tür paylaşımların hiçbir koşulda kabul edilemez olduğu

-Paylaşımların neden olabileceği olumsuz sonuçlar

-Sosyal medya paylaşımları ile ilgili ileride karşılaşılacak muhtemel hukuki problemler konularını içeren bir program ile annelere, "Sosyal Medyada Çocuk Hakları İhlali ve Çocuk İstismarı" ile ilgili farkındalık eğitimleri verilmelidir.

İstismarın önlenmesi çalışmaları içerisinde anne-babalara yönelik eğitimler de yer almalıdır. Çocuk istismarı ile ilgili yapılan çalışmalarda, istismarcının daha çok aile içinden ve yakın akrabalardan çıktığı düşünüldüğünde "akraba-yabancı" ayırımı da giderek silikleşmektedir. Özellikle ebeveynlerin toplumsal davranış kıskacından kurtularak çocuklarına yönelik her türlü davranışı sağduyulu değerlendirmeleri gerekir. Aileler çocuklarını, "akrabalar ve yabancılarla" iletişim kurarken her ikisi arasında kademeli bir yakınlık kurmaları konusunda eğitmelidir.

Ebeveyn eğitimi, sorunun çözümüne ilişkin etkili olacak bir yöntemdir. Ancak çocuğun kendi hakları ile ilgili bilinç düzeyinin arttırılması, dijital dünya ile birlikte günlük hayatta da çocuğun yararına olacaktır. Çocukların, başkaları tarafından fotoğrafları 
çekilmeden önce rıza göstermeleri ve istemedikleri takdirde "hayır" demeleri gerektiği öğretilmelidir. Bu çalışmalar, eğitim kurumlarında çocuk istismarı ile ilgili verilecek temel eğitimlerin bir parçası olmalıdır. Örgün eğitim içerisinde yer alacak bilgilendirmeler ile tüm çocuklar erken yaşta cinsel istismar ile çocuk hakları konusunda bilgilendirilmelidir. Bu eğitimlerin kapsamı mahremiyet, bedenin dokunulmazlığı, hayır demeyi öğrenmek, istismarı sevgiden ayırt edebilmek olmalıdır (Bulut, 2007: 150).

Çocuğun korunması, aile ile birlikte devletin de görevleri arasındadır. Bu nedenle çocuğun korunması ile ilgili alınacak önlemlerin içerisinde çocuğun mahremiyetinin korunması üzerinde önemle durulmalıdır. Çocuk hakları ile ilgili düzenlemelerde, "özel yaşamın gizliliği”" yahut "unutulma hakkı" gibi ucu açı ve muğlâk ifadeleri barındirmamalıdır.

Medya, çocuk istismarı ile ilgili farkındalık yaratmak için etki alanı geniş bir mecradır. Bu nedenle ilgili bakanlıklarla birlikte hazırlanacak kamu spotları, aynı anda milyonlarca ebeveyne ulaşacaktır. Bu çalışmalar neticesinde, sosyal medyada çocuk hakları ihlali ve istismarı konusunda farkındalık kazanmış bir ebeveyn, yine çocuğuna edeceği rehberlik ile haklarının farkında olan ve kendini koruma bilinci yerleşmiş nesiller yetiştirecektir.

\section{Kaynaklar}

Akyüz, E. (25-27 Şubat 2011). Çocuk Hukukun Gelişimi ve Koruma Sisteminin Değerlendirilmesi. 1. Türkiye Çocuk Hakları Kongresi Yetişkin Bildirileri Kitabı. İstanbul: Çocuk Vakfı Yayınları.

AVG Technologies (2010). AVG Digital Diaries - A Look At How Technology Affectsus From Birth Onwards. Erişim adresi: http://www.avgdigitaldiaries.com/ post/41940227757/avg-digital-diaries-a-look-at-how-technology ( 3 Ocak 2019).

Bayraktar, S, (2015). İnsanlığın Kanayan Yarası Çocuk İstismarı ve İhmali, İstanbul: Nobel Tip Kitabevleri.

Bilir, M. (2017). Sosyal Medya ve Çocuk. Yayınlanmamış Yüksek Lisans Bitirme Ödevi. Ankara: Hacettepe Üniversitesi Sosyal Bilimler Enstitüsü Bilişim Hukuku.

Bulut, S. (2007). Çocuk Cinsel İstismarı Hakkında Bir Derleme. Türk Psikoloji Danışma ve Rehberlik Dergisi, 28 (3), 139-156.

Çimke, S., Gürkan, D. Y. ve Polat S, (2018). Sosyal Medyada Çocuk Hakkı İhlali: Sharenting, Güncel Pediatri, 16 (2), 261-267.

Çocuk Hakları İhlali ve Çocukların İstismarAlanı Olarak ' Sosyal Medya"'(Bölüm II) Erişim adresi:https://www.linkedin.com/pulse/\%C3\%A7ocuk-haklar\%C4\%B1-ihlali-ve$\% \mathrm{C} 3 \% \mathrm{~A} 7$ ocuklar$\% \mathrm{C} 4 \% \mathrm{~B} 1 \mathrm{n}$-istismar-alan $\% \mathrm{C} 4 \% \mathrm{~B} 1$-ii-hablemito $\% \mathrm{C} 4 \% 9 \mathrm{Flu}$ ?trk=mpreader-card (11 Ocak 2019)

Dursun, C. (2019). Ebeveynlerin Çocuklarını Sosyal Medyada Teşhiri: Çocuk Hakları Bağlamında Bir Değerlendirme. Çocuk ve Medeniyet Dergisi, 2, 195-208. 
Duygulu, S. (2019). Sosyal Medyada Çocuk Fotoğrafı Paylaşımlarının Mahremiyet İhlali ve Çocuk İstismarı Açısından Değerlendirilmesi. TRT Akademi, 4(8), 428-487.

Erişir, R. M., Erişir D. (2018). Yeni Medya ve Çocuk: Instagram Özelinde "Sharenting" ("Paylaşanababalık") Örneği. Yeni Medya, Sayı: 4-5, 50-64.

Family Online Safety Institute, (2015). Parents, Privacy and Technology Use. Erişim adresi: global-uploads.webflow.com/5f4dd3623430990e 705ccbba/5f6eb6405dd3 54294d1db71c_Full_Report--Web.pdf (10 Şubat 2019).

Güngör, A. (2019). Sosyal Medyada Çocuk Hakları İhlali ve İstismarı. (Yüksek Lisans Tezi). YÖK Tez Merkezi. (551019).

İnan, A. N. (1968). Çocuk Hukuku, İstanbul: Ankara Üniversitesi.

Kuruoğlu, H. Soygüder, Ş, (2009), Televizyon Reklamlarında Çocuk: Türkiye Örneği, Akçalı, İ. S (Ed.), Çocuk ve Medya, Ankara: Nobel Yayınları.

Netnografi. Erişim adresi: https://kozinets.net/ (27 Şubat 2019).

Numedov, Serdar (2016), Bir bağımlılık Olarak İnternet. http://slideplayer.biz.tr/ slide/3005393\%20(01/12/2016) (13 Aralık 2018)

Özbölük, T ve Dursun, Y, (2015). Pazarlama Araştırmalarında Paradigmal Dönüşüm ve Etnografinin Dijitale Evrimi: Netnografi. Erciyes Üniversitesi İktisadi ve İdari Bilimler Fakültesi Dergisi, Say1 46, 227-249.

Parents on Social Media: Likes and Dislikes of Sharenting. (2015). Erişim adresi: https://mottpoll.org/sites/default/files/documents/031615_sharenting_0.pdf (2 Şubat 2019).

Parmaksız Y. P. M (2012). Digital Opportunities for Social Transition: Blogosphere and Motherhood in Turkey. Fe Dergi, 4(1), 123-134.

Şirin, R. M., Oktay, N., Altun, A. (2013). I. Türkiye Çocuk ve Medya Stratejisi ve Uygulama Planı 2014-2018. 1. Türkiye Çocuk Kongresi, İstanbul: Çocuk Vakfı Yayınları.

Teke, S, (2014). Dönüşen Anneliğe Yönelik Netnografik Bir Analiz: Blogger Anneler. Millî Folklor, Sayı 103, 32-47.

Timisi, N. (2011). Medyada Çocukları Koruyucu Önlemler. 1. Türkiye Çocuk Hakları Kongresi. İstanbul: Çocuk Vakfı Yayınları.

TÜİK. (2020). Adrese Dayalı Nüfus Kayıt Sistemi Sonuçları. Erişim adresi: https://data.tuik.gov.tr/Bulten/Index? $\mathrm{p}=$ Adrese-Dayali-Nufus-Kayit-SistemiSonuclari-2020-37210 (09 Mayıs 2021).

Tüzün, Ü. (2002). Gelişen İletişim Araçlarının Çocuk ve Gençlerin Etkileşimi Üzerine Etkisi. Düşünen Adam Dergisi, 15(1), 46-50.

Uğurlu, G. E., Uğurlu H. (2017). 2017 Reklamlarda Çocuk Karakterlerin Kullanımı: Türkiye Örneği. Gümüşhane Üniversitesi Sosyal Bilimler Enstitüsü Elektronik Dergisi, 8 (19), 19-36.

UNICEF. (2017) A Familiar Face: Violence İn The Lives Of Children And 
Adolescents. New York. Erişim adresi: https://www.unicef.org/publications/files/ Violence_in_the_lives_of_children_and_adolescents.pdf

UNICEF Ne Yapar? Erişim adresi: https://www.unicef.org/turkey/neyap\%C4\%B1yoruz (25 Aralık 2018).

Whitehead, D. (2015). The Evidence of Things Unseen: Authenticity and Fraud in the Christian Mommy Blogosphere. Journal of the American Academy of Religion, 83(1), 120-150.

Yavuz, C. (2020). Sosyal Medya Ebeveynliği ve Çocukların Unutulma Hakkı. İzmir Barosu Dergisi, 85 (1), 15-52.

Yüksel, M. (2003). Mahremiyet Hakkı ve Sosyo-Tarihsel Gelişimi. Ankara Üniversitesi Siyasal Bilgiler Fakültesi Dergisi, 58(1), 181-213.

Destekleyen Kurum/Kuruluşlar: Herhangi bir kurum/kuruluştan destek alınmamıştır.

Çıkar Çatışması: Herhangi bir çıkar çatışması bulunmamaktadır. 